\title{
Study on Morbidity and Mortality Rates in Buffaloes in Pune Division of Maharashtra State in India
}

\author{
Y.C. Bangar ${ }^{1, *}$, T.A. Khan ${ }^{1}$, A. Dohare ${ }^{1}$, D.V. Kolekar ${ }^{2}$ and S.R. Avhad ${ }^{2}$ \\ ${ }^{1}$ Division of LES \& IT and ${ }^{2}$ Division of Veterinary Extension Education, Indian Veterinary Research Institute \\ (IVRI), Izatnagar, U.P., India
}

\begin{abstract}
The present study was carried out to analyse morbidity and mortality rate in buffaloes and its associated factors in Pune division of Maharashtra state in India. Stratified two stages random sampling design was adopted \& the data of total 564 buffaloes were collected through pre-tested modified schedule from 157 buffalo owners. The data were analysed statistically by SAS 9.3 software for evaluation of Chi-square and Logistic regression analysis. Overall morbidity $(28.01 \%)$ and mortality $(7.98 \%)$ rates were recorded in study area. Digestive diseases and respiratory diseases are major cause of the higher morbidity and mortality in buffaloes, respectively. Statistically, there wasn't significant association of overall disease incidence with age or sex. However, the Chi-square analysis of overall mortality rate showed significance $(p<0.01)$ difference among age and sex. Logistic regression analysis also suggested the same results. Mortality rates were recorded higher in calves and male buffaloes as compared to their respective counterparts. It is suggested that digestive and respiratory problems may be reduced by improving feeding and management practices. This study provides the important tool for determining the health status of buffaloes and has special importance in planning of prevention and control strategies designed to reduce the incidences of diseases in livestock and therefore economic status of farmers.
\end{abstract}

Keywords: Buffalo, Digestive, Respiratory, Chi-square, Logistic.

\section{INTRODUTION}

India possesses first rank in world buffalo population and in 2012 year, India had 115.4 million buffalo population [1]. Out of total estimated milk production in India (127.9 million tonnes) during 201112 , buffaloes contributing 65.4 million tonnes $(51.13 \%)$ milk [2]. Despite of high population, animal health and production status is not at greater extent mainly because of incidences and deaths due to various diseases which resulting into heavy economic losses to farmers. Morbidity and mortality have been the indicators of overall health among the animal population. Many livestock diseases have different morbidity and mortality pattern in respect to species, time and place, hence to understand their behaviour and to identify factors responsible for the same, specific intervention could be introduced at proper time for minimizing the economic losses due to diseases. Digestive disease and respiratory disease are major cause of the highest morbidity and mortality in buffaloes [3]. Calf-diarrhoea is the major (54.37\%) cause of morbidity in buffalo calves [4]. In view of increasing demand for milk and meat, more and more emphasis is being placed on the improvement of health and productive potentials of buffaloes. In the present paper an attempt is made to study the morbidity and mortality in buffaloes in Pune division of Maharashtra state of India.

*Address correspondence to this author at the Division of LES \& IT, Indian Veterinary Research Institute (IVRI), Izatnagar, U.P., India;

Tel: +919027586031; E-mail: yogeshbangar07@gmail.com

\section{MATERIALS AND METHODS}

\section{Sampling Design}

This study was carried out in Pune division of Maharashtra state of India for 2010 year on the basis of farmer's interview. Total 157 buffalo owners were selected by stratified two stages random sampling and each selected buffalo owner was enumerated completely to collect the required information regarding demography, morbidity and mortality in buffaloes due to various disorders using pre-tested modified schedule.

\section{Data Variables}

Data on age of buffaloes were later categorized in two groups such as calves ( $\leq 1$ year age) and Adults (>1 year age). Another variable, sex of animal, was represented in two categories i.e. male and female. The diseases observed during the study period were classified as Digestive, respiratory, reproductive, parasitic, specific, nutritional, injuries and other diseases categories [5].

\section{Statistical Analysis}

Morbidity rates and mortality rates were calculated on the basis of total prevalence during the period [6]. Chi-square test $\left(\chi^{2}\right)$ was used to study association between disease category with age as well as with sex of animal. A binary logistic model was fitted to the data to test the research hypothesis regarding the 
relationship between risk of disease incidence (or death) and two-predictor (Age and Sex) and given as,

$$
\text { Logit }(P)=\log \left(\frac{P}{1-P}\right) \beta_{0}+\beta_{1} * \text { Age }+\beta_{2} * \operatorname{Sex}
$$

Chi-square and Logistic regression analysis was carried out by PROC FREQ and PROC LOGISTIC in SAS 9.3 version.

\section{RESULTS}

A total of 564 buffaloes were maintained by 157 buffalo's owners in study period. Out of 564 buffaloes, young (less than one year) and adult (greater than one year) buffaloes were 125 (22.16\%) and 439 (77.84\%), respectively. Percentages of male and females buffaloes were $12.77 \%$ and $87.23 \%$, respectively. Disease-wise morbidity and mortality rates are shown in Figure 1. The overall morbidity and mortality rates in buffaloes were $28.01 \%$ \& $7.98 \%$, respectively. Morbidity and mortality rates (\%) due to various diseases in buffaloes with respect to age and sex are shown in Table 1-2. Logistic regression for analysing relative effect of age and sex of buffalo with overall morbidity and mortality rates are shown in Tables 3, 4 .

\section{DISCUSSION}

In present study, an attempt was made to understand association of age and sex with incidences and deaths due to various diseases in buffaloes in Pune division of Maharashtra state in India. Disease-

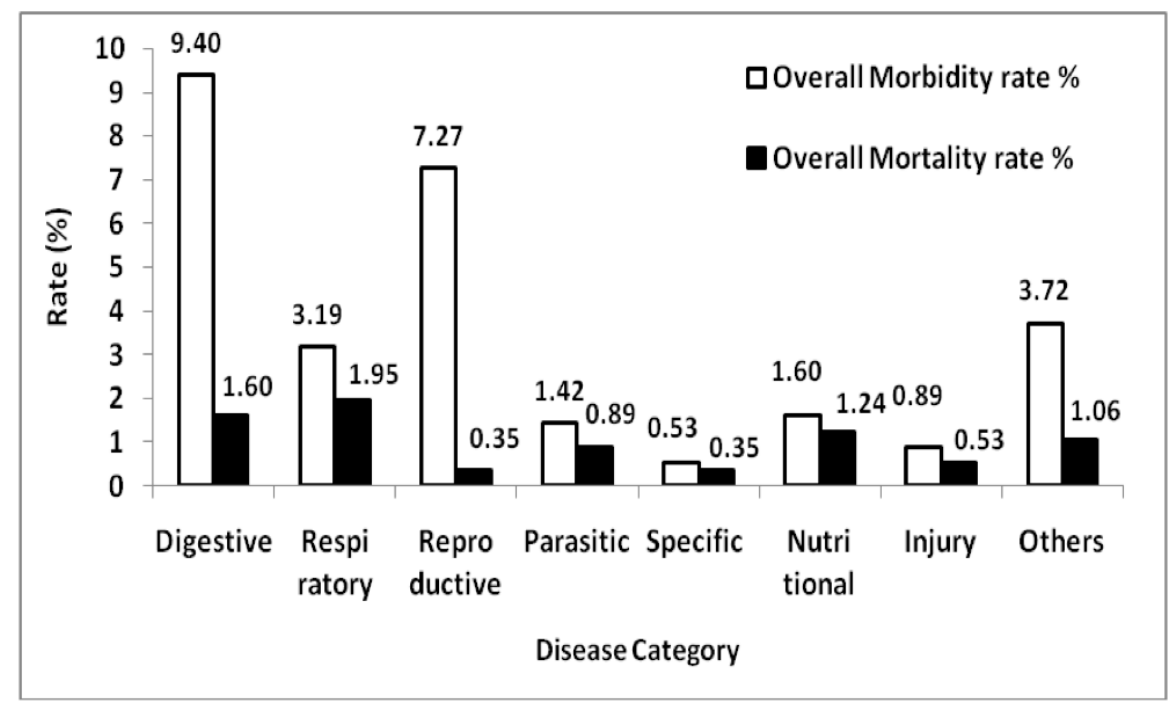

Figure 1: Disease-wise overall morbidity and mortality rates in buffaloes.

Table 1: Morbidity Rates (\%) Due to Various Diseases in Buffaloes

\begin{tabular}{|c|c|c|c|c|c|c|c|}
\hline \multirow{2}{*}{ Diseases } & \multicolumn{2}{|c|}{ Age } & \multirow{2}{*}{$\chi^{2}$} & \multicolumn{2}{|c|}{ Sex } & \multirow{2}{*}{$\begin{array}{c}\chi^{2} \\
\text { p value }\end{array}$} \\
\cline { 2 - 3 } & \multirow{2}{*}{$\begin{array}{c}\text { Calves } \\
\text { (125) }\end{array}$} & $\begin{array}{c}\text { Adults } \\
\mathbf{( 4 3 9 )}\end{array}$ & p value & $\begin{array}{c}\text { Male } \\
\text { (72) }\end{array}$ & $\begin{array}{c}\text { Female } \\
\text { (492) }\end{array}$ & \\
\hline \hline Digestive (\%) & 2.40 & 11.39 & 0.01 & 4.17 & 10.16 & 0.1 \\
\hline Respiratory (\%) & 10.40 & 1.14 & $<0.001$ & 5.56 & 2.85 & 0.22 \\
\hline Reproductive (\%) & 0.00 & 9.34 & NA & 0.00 & 8.33 & NA \\
\hline Parasitic (\%) & 4.80 & 0.46 & $<0.01$ & 2.78 & 1.22 & 0.3 \\
\hline Specific (\%) & 0.00 & 0.68 & NA & 0.00 & 0.61 & NA \\
\hline Nutritional (\%) & 6.40 & 0.23 & $<0.001$ & 8.33 & 0.61 & $<0.001$ \\
\hline Injury (\%) & 2.40 & 0.46 & 0.04 & 1.39 & 0.81 & 0.63 \\
\hline Others (\%) & 4.80 & 3.42 & 0.47 & 5.56 & 3.46 & 0.38 \\
\hline Total Affected (\%) & 31.20 & 27.11 & 0.37 & 27.78 & 28.05 & 0.96 \\
\hline
\end{tabular}

NA- Not applicable. 
Table 2: Mortality Rates (\%) Due to Various Diseases in Buffaloes

\begin{tabular}{|c|c|c|c|c|c|c|}
\hline \multirow[b]{2}{*}{ Diseases } & \multicolumn{2}{|c|}{ Age } & \multirow{2}{*}{$\begin{array}{c}\chi^{2} \\
p \text { value }\end{array}$} & \multicolumn{2}{|c|}{ Sex } & \multirow{2}{*}{$\begin{array}{c}\chi^{2} \\
\text { p value }\end{array}$} \\
\hline & $\begin{array}{c}\text { Calves } \\
(125)\end{array}$ & $\begin{array}{c}\text { Adults } \\
\text { (439) }\end{array}$ & & $\begin{array}{c}\text { Male } \\
(72)\end{array}$ & $\begin{array}{c}\text { Female } \\
(492)\end{array}$ & \\
\hline Digestive (\%) & 2.40 & 1.37 & 0.42 & 4.17 & 1.22 & 0.62 \\
\hline Respiratory (\%) & 8.00 & 0.23 & $<0.001$ & 2.78 & 1.83 & 0.59 \\
\hline Reproductive (\%) & 0.00 & 0.46 & NA & 0.00 & 0.41 & NA \\
\hline Parasitic (\%) & 4.00 & 0.00 & NA & 2.78 & 0.61 & 0.07 \\
\hline Specific (\%) & 0.00 & 0.46 & NA & 0.00 & 0.41 & NA \\
\hline Nutritional (\%) & 5.60 & 0.00 & NA & 8.33 & 0.20 & $<0.001$ \\
\hline Injury (\%) & 2.40 & 0.00 & NA & 1.39 & 0.41 & 0.29 \\
\hline Others (\%) & 4.00 & 0.23 & $<0.001$ & 4.17 & 0.61 & 0.01 \\
\hline Total Affected (\%) & 26.40 & 2.73 & $<0.01$ & 23.61 & 5.69 & $<0.01$ \\
\hline
\end{tabular}

NA- Not applicable.

Table 3: Logistic Regression Analysis of the Risk of Overall Morbidity in Buffaloes

\begin{tabular}{|c|c|c|c|c|c|c|c|}
\hline Variable & Level & Estimate & S.E. & Wald & D.F. & Sig. & Odds Ratio \\
\hline \hline Intercept & & -0.98 & 0.11 & 78.25 & 1 & $<0.001$ & 0.37 \\
\hline Age & Calves & 0.20 & 0.22 & 0.83 & 1 & 0.36 & 1.23 \\
\hline & Adults & Reference category & & & & 1 \\
\hline Sex & Male & -0.05 & 0.28 & 0.03 & 1 & 0.87 & 0.95 \\
\hline & Female & Reference category & & & & 1 \\
\hline
\end{tabular}

Table 4: Logistic Regression Analysis of the Risk of Overall Mortality in Buffaloes

\begin{tabular}{|c|c|c|c|c|c|c|c|}
\hline Variable & Level & Estimate & S.E. & Wald & D.F. & Sig. & Odds Ratio \\
\hline \hline Intercept & & -3.84 & 0.32 & 148.33 & 1 & $<0.001$ & 0.02 \\
\hline Age & Calves & 2.46 & 0.36 & 45.79 & 1 & $<0.001$ & 11.65 \\
\hline & Adults & Reference category & & & & 1 \\
\hline Sex & Male & 1.43 & 0.38 & 14.27 & 1 & $<0.001$ & 4.16 \\
\hline
\end{tabular}

wise morbidity rates were high for digestive diseases followed by reproductive disorders while respiratory diseases were more common causes for mortality.

Overall morbidity rate was found higher in calves than adults. Similar findings also reported by Saeed and Ali [7] and Balakrishnan et al. [8]. Although overall morbidity pattern is not significantly $(p>0.05)$ different among age and sex, respiratory diseases had significantly $(p<0.001)$ higher morbidity in calves and digestive diseases were prominent in adult buffaloes. Nutritional deficiencies were observed significantly $(p<0.001)$ more in males than females. The reason for this may be given fact that more care is given to female buffaloes due to their economic importance as compared to their male counterparts. This malpractice was common in study area.

Overall mortality rate in buffaloes were significantly $(p<0.01)$ different among age and sex (Table 2). Calves were at high risk of mortality than the adults. The similar results were reported by Rathore [9] and Pradhan and Panda [10]. The higher mortality in calves might be due to they have low immunity, so more 
susceptible to diseases. Major cause for deaths in calves was respiratory diseases. Similar findings were also reported by Hashmi [11].

The age-wise mortality rates in buffaloes are in agreement with Khan and Khan [12] and Jindal et al. [13]. Male were at greater risk of mortality than that of female. The similar results were reported by Kumar et al. [14] as nutritional diseases were predominant in males as compared to females.

Logistic regression analysis of overall morbidity data revealed that age and sex were not significantly $(p>0.05)$ associated with overall morbidity in buffaloes (Table 3). The overall logistic regression analysis of mortality data revealed significance $(p<0.001)$ difference between age groups and observed that calves were at greater $(\mathrm{OR}=11.65)$ risk of mortality than adult buffaloes $(\mathrm{OR}=1.00)$ (Table 4). Males were at greater $(\mathrm{OR}=4.16)$ risk of mortality than their counterparts $(\mathrm{OR}=1.00)$.

\section{CONCLUSION}

In conclusion it can be said that digestive diseases, respiratory diseases and nutritional diseases were major problems to causing economic losses to farmers in the study area. These problems can tackle by providing feeding and management practices. Males and calves were more susceptible to mortality; therefore special care is essential to this segment. This study provides the important tool for determining and thereafter improving the health status of buffaloes in the study area. Further study on morbidity and mortality with respect to managemental aspects is recommended.

\section{ACKNOWLEDGMENTS}

All authors are thankful to Head of LES \& IT and Director, IVRI for providing necessary facility to carry out the study.

\section{REFERNCES}

[1] Food and Agricultural organization of the United nations. 2013. http://faostat.fao.org/site/573/DesktopDefault.aspx? PagelD $=573$ \#ancor

[2] Basic Animal Husbandry statistics 2013. Department of Animal Husbandry, Dairying \& Fisheries. http://dahd.nic.in/ dahd/statistics/animal-husbandry-statistics.aspx

[3] Zaman T, Khan A, Akhtar MZ. Some of the risk factors of NiliRavi buffalo (Bubals bubalis) neonatal calf mortality in Pakistan. Pakistan Vet J 2006; 121-25.

[4] Malik S, Verma A, Kumar A, Gupta MK, Sharma SD. Incidence of calf diarrhea in cattle and buffalo calves in Uttar Pradesh, India. Asian J Anim Vet Adv 2012; 7(10): 1049-54. http://dx.doi.org/10.3923/ajava.2012.1049.1054

[5] Prasad S, Ramachandran N, Raju S. Mortality patterns in dairy animals under organised herd management conditions at Karnal, India. Trop Anim Health Prod 2004; 36: 645-54 http://dx.doi.org/10.1023/B:TROP.0000042855.58026.bd

[6] Dana SS, Rathore BS, Kaul PN. Morbidity and mortality pattern in desi cattle reared by the Santal tribe of West Bengal. Indian J Anim Res 2001; 35(1): 47-49.

[7] Saeed A, Ali S. Monitoring of bovine health small dairy herds in Islamabad capital territory: design, data and disease frequencies. Trop Anim Health Prod 1994; 26: 1934-98.

[8] Balakrishnan M, Ramesha KP, Sreenath M, Kumar S. Factors affecting mortality of buffalo calves in an organised herd. Indian J Dairy Biosci 1996; 7: 61-65.

[9] Rathore BS. An epidemiological study on buffalo morbidity and mortality based on four year observations on 18630 buffaloes maintained at 28 livestock farms in India. Indian $\mathrm{J}$ Comp Microbiol Immunol Infect Dis 1998; 19(1): 43-49.

[10] Pradhan B, Panda GM. Calving pattern and mortality trends in Murrah buffalo calves reared under Orissa condition. Indian J Anim Prod Manag 1994; 10(4): 143-46.

[11] Hashmi HA, Tarique TM, Yang $S$, et al. Factors affecting mortality in buffaloes and calves. International J Agric Sci Vet Med 2013; 1(2): 1-6.

[12] Khan A, Khan MZ. Neonatal calf mortality in Pakistan. I: prevalence and factors influencing mortality in buffalo and cow neonates Buffalo J 1996; 12(2): 219-29.

[13] Jindal N, Kumar S, Narang G, Chaturvedi GC, Tomer P, Garg DN. Some epidemiological observations on haemorrhagic septicaemia in buffaloes and cattle in Haryana State of India. Buffalo J 2002; 18(2): 273-80.

[14] Kumar CR, Moorthy PRS, Rao KS, Naidu KV. Calf mortality pattern in relation to age and sex in organized livestock farms in Andhra Pradesh. Indian J Anim Sci 2002; 72(10): 921-23. 